\title{
ISOCOMPLESTATIN: TOTAL SYNTHESIS AND STEREOCHEMICAL REVISION
}

\author{
Toshio Shinohara, Hongbo Deng, Marc L. Snapper,* and Amir H. Hoveyda* \\ Department of Chemistry, Merkert Chemistry Center, Boston College \\ Chestnut Hill, Massachusetts 02467
}

\section{SUPPORTING INFORMATION}

General. Infrared (IR) spectra were recorded on a Perkin Elmer 781 spectrophotometer. ${ }^{1} \mathrm{H}$ NMR spectra were recorded on a Varian Unity Inova $400(400 \mathrm{MHz})$ or Varian Unity Inova $500(500 \mathrm{MHz})$. Chemical shifts are reported in $\mathrm{ppm}$ from tetramethylsilane with the solvent resonance resulting from incomplete deuteration as the internal reference $\left(\mathrm{CDCl}_{3}: \delta 7.26 \mathrm{ppm}\right.$, acetone- $d_{6}: \delta 2.05 \mathrm{ppm}, \mathrm{CD}_{3} \mathrm{OD}: \delta 3.31 \mathrm{ppm}$, DMSO- $\left.d_{6}: \delta 2.50 \mathrm{ppm}\right)$ or relative to tetramethylsilane (0.0). Data are reported as follows: chemical shift, multiplicity ( $\mathrm{s}=$ singlet, $\mathrm{d}=$ doublet, $\mathrm{t}=$ triplet, $\mathrm{q}=$ quartet, $\mathrm{br}=$ broad, $\mathrm{m}=$ multiplet), coupling constants $(\mathrm{Hz})$, number of protons. ${ }^{13} \mathrm{C}$ NMR spectra were recorded on a Varian Unity Inova $(100 \mathrm{MHz})$ or Varian Unity Inova $500(125 \mathrm{MHz})$ with complete proton decoupling. Chemical shift are reported in ppm from tetramethylsilane with the solvent as the internal reference $\left(\mathrm{CDCl}_{3}: \delta 77.16 \mathrm{ppm}\right.$, acetone- $d_{6}: \delta$ $\left.29.84 \mathrm{ppm}, \mathrm{CD}_{3} \mathrm{OD}: \delta 49.00 \mathrm{ppm}, \mathrm{DMSO}-d_{6}: \delta 39.52 \mathrm{ppm}\right)$. High-resolution mass spectrometry was performed at the Mass Spectrometry Facility, Boston College on a Micromass LCT ESI-MS (positive mode). Optical rotations were determined through a Rudolph Research Analytical Autopol IV polarimeter and are reported as follows: $[\alpha]_{D}^{\text {temp }}$, concentration $(\mathrm{c}=\mathrm{g} / 100 \mathrm{~mL})$, solvent. All reactions were conducted in oven $\left(135^{\circ} \mathrm{C}\right)$ and flame-dried glassware under atmosphere of dry Ar or $\mathrm{N}_{2}$.

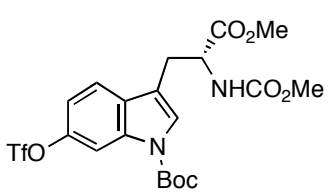

Aryltriflate 5. A solution of phenol $4(1.02 \mathrm{~g}, 3.05 \mathrm{mmol})$ in $10 \% \mathrm{H}_{2} \mathrm{SO}_{4}$ in $\mathrm{MeOH}(30 \mathrm{~mL})$ was allowed to stir for $1 \mathrm{~h}$ at $22{ }^{\circ} \mathrm{C}$ and then poured into a saturated solution of $\mathrm{NaHCO}_{3}$. After removal of $\mathrm{MeOH}$ in vacuo, the mixture was washed with EtOAc $(20 \mathrm{~mL} \times 3)$. The resulting extracts were washed with brine, dried over $\mathrm{MgSO}_{4}$ and concentrated in vacuo to afford the corresponding 6-hydroxytryptophan derivative $(808 \mathrm{mg})$. 6-Hydroxytryptophan derivative $(808 \mathrm{mg})$ was dissolved in $\mathrm{CH}_{2} \mathrm{Cl}_{2}(14 \mathrm{~mL})$ and cooled to $-78{ }^{\circ} \mathrm{C}$. Triethylamine $(461 \mu \mathrm{L}, 3.31 \mathrm{mmol})$ and $\mathrm{Tf}_{2} \mathrm{O}(511 \mu \mathrm{L}, 3.04 \mathrm{mmol})$ were added to this mixture, which was allowed to stir for $3 \mathrm{~h}$. At this time, the reaction was quenched by the addition of a saturated solution of $\mathrm{NaHCO}_{3}$. The mixture was washed with $\mathrm{CH}_{2} \mathrm{Cl}_{2}(15 \mathrm{~mL} \times 3)$. The organic layers were washed with brine, dried over $\mathrm{MgSO}_{4}$, and concentrated in vacuo to give the desired triflate as a colorless oil $(1.17 \mathrm{~g})$. To a solution of triflate in $\mathrm{CH}_{2} \mathrm{Cl}_{2}(14 \mathrm{~mL})$ was added triethylamine (461 $\left.\mu \mathrm{L}, 3.31 \mathrm{mmol}\right)$, Boc $2 \mathrm{O}$ (720 mg, $3.30 \mathrm{mmol})$, and DMAP $(1-2 \mathrm{~mol} \%)$. The mixture was allowed to stir at $22{ }^{\circ} \mathrm{C}$ for $10 \mathrm{~h}$. The reaction was quenched by the addition of water, and the resulting mixture was washed with $\mathrm{CH}_{2} \mathrm{Cl}_{2}(15 \mathrm{~mL} \times 3)$. The organic layers were washed with brine, dried over $\mathrm{MgSO}_{4}$, and concentrated in vacuo. The residue was purified by silica gel chromatography (2:1 to 1:1 hexanes:EtOAc) to provide the desired triflate 5 a colorless oil $(1.15 \mathrm{~g}, 2.19 \mathrm{mmol}, 72 \%$ overall yield for 3 steps). ${ }^{1} \mathrm{H} \mathrm{NMR}\left(\mathrm{CDCl}_{3}, 400 \mathrm{MHz}\right): \delta 8.08(\mathrm{br}, 1 \mathrm{H}), 7.53(\mathrm{~d}, J=8.4 \mathrm{~Hz}, 1 \mathrm{H}), 7.49(\mathrm{~s}, 1 \mathrm{H}), 7.16(\mathrm{dd}$, $J=8.8,2.4 \mathrm{~Hz}, 1 \mathrm{H}), 5.32(\mathrm{~d}, J=7.6 \mathrm{~Hz}, 1 \mathrm{H}), 4.73-4.65(\mathrm{~m}, 1 \mathrm{H}), 3.69(\mathrm{~s}, 3 \mathrm{H}), 3.68(\mathrm{~s}, 3 \mathrm{H}), 3.28-3.16(\mathrm{~m}, 2 \mathrm{H}), 1.67(\mathrm{~s}$, 9H). ${ }^{13} \mathrm{C} \mathrm{NMR}\left(\mathrm{CDCl}_{3}, 100 \mathrm{MHz}\right): \delta 171.8,156.3,148.9,146.9,130.1,126.1,120.4,119.8,117.2,116.0,114.7,109.0$, 84.9, 53.9, 52.5, 52.4, 28.0, 27.8. HRMS (TOF): $\mathrm{m} / z$ calcd for $\mathrm{C}_{20} \mathrm{H}_{24} \mathrm{~N}_{2} \mathrm{O}_{9} \mathrm{SF}_{3}: 525.1155$, found: $525.1163[\mathrm{M}+\mathrm{H}]^{+}$. $[\alpha]^{26}=-9.4(c=1.2$, acetone $)$.

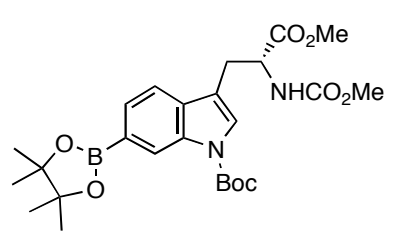

Boronic ester 6. A solution of triflate 5 (1.13 g, $2.15 \mathrm{mmol})$, bis(pinacolato)diboron (655 $\mathrm{mg}, 2.58 \mathrm{mmol}), \mathrm{PdCl}_{2}(\mathrm{dppf}) \cdot \mathrm{CH}_{2} \mathrm{Cl}_{2}$ (10 mol \%, $\left.171 \mathrm{mg}, 0.21 \mathrm{mmol}\right)$, dppf (12 mol \%, 139 $\mathrm{mg}, 0.25 \mathrm{mmol})$, and KOAc $(633 \mathrm{mg}, 6.45 \mathrm{mmol})$ in degassed 1,4-dioxane $(22 \mathrm{~mL})$ was allowed to stir at $80{ }^{\circ} \mathrm{C}$ for $3 \mathrm{~h}$. The reaction was quenched by the addition of water, and the resulting mixture was washed with EtOAc $(30 \mathrm{~mL}$ x 3). The organic layers were 
washed with brine, dried over $\mathrm{Na}_{2} \mathrm{SO}_{4}$, and concentrated in vacuo to yield brown solid. The solid was purified by silica gel chromatography (2:1 hexanes:EtOAc) to give the desired compound (6) as a yellow solid $(930 \mathrm{mg}, 1.85 \mathrm{mmol}, 86 \%$ yield). $\quad{ }^{1} \mathrm{H} \mathrm{NMR}\left(\mathrm{CDCl}_{3}, 400 \mathrm{MHz}\right): \delta 8.62(\mathrm{br}, 1 \mathrm{H}), 7.66(\mathrm{~d}, J=8.0 \mathrm{~Hz}, 1 \mathrm{H}), 7.47(\mathrm{~d}, J=8.0 \mathrm{~Hz}, 1 \mathrm{H}), 7.43(\mathrm{~s}, 1 \mathrm{H})$, $5.29(\mathrm{~d}, J=8.0 \mathrm{~Hz}, 1 \mathrm{H}), 4.73-4.68(\mathrm{~m}, 1 \mathrm{H}), 3.67(\mathrm{~s}, 3 \mathrm{H}), 3.30-3.20(\mathrm{~m}, 1 \mathrm{H}), 1.68(\mathrm{~s}, 9 \mathrm{H}), 1.35(\mathrm{~s}, 12 \mathrm{H}) .{ }^{13} \mathrm{C} \mathrm{NMR}$ $\left(\mathrm{CDCl}_{3}, 100 \mathrm{MHz}\right): \delta 172.1,156.4,149.5,135.3,132.9,128.6,125.4,122.0,118.2,114.9,83.8,54.2,52.5,52.4,28.3$, 27.9, 25.1, 25.0. HRMS (TOF): $\mathrm{m} / z$ calcd for $\mathrm{C}_{25} \mathrm{H}_{36} \mathrm{BN}_{2} \mathrm{O}_{8}: 503.2565$, found: $503.2580[\mathrm{M}+\mathrm{H}]^{+} . \quad[\alpha]^{26}{ }_{\mathrm{D}}=+0.83(c=$ 1.1 , acetone).

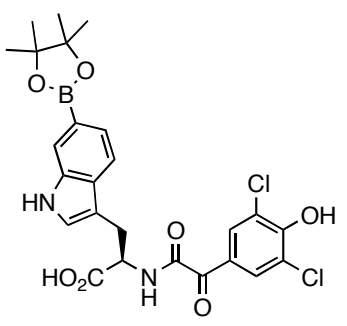

Boronic ester 8. TMSI $(228 \mu \mathrm{L}, 1.6 \mathrm{mmol})$ was added to a solution of boronate 6 (200 $\mathrm{mg}$, $0.4 \mathrm{mmol})$ in $\mathrm{CHCl}_{3}(4 \mathrm{~mL})$ at $0{ }^{\circ} \mathrm{C}$. The mixture was heated to $50^{\circ} \mathrm{C}$ for $1 \mathrm{~h}$, followed by the addition of $\mathrm{MeOH}(1 \mathrm{~mL})$. The mixture was allowed to stir for $1 \mathrm{~h}$, after which volatiles were removed in vacuo. The resulting residue was dissolved in $\mathrm{MeOH}(1 \mathrm{~mL})$ and the solution neutralized by the addition of triethylamine $(\sim 300 \mu \mathrm{L})$. Volatiles were removed and the resulting residue was dissolved EtOAc $(10 \mathrm{~mL})$, which was washed with a saturated solution of $\mathrm{NaHCO}_{3}$ followed by brine. The solution was dried over $\mathrm{MgSO}_{4}$ and volatiles were removed under reduced pressure to afford the derived amine. The resulting amine was dissolved in THF $(4 \mathrm{~mL})$ and to this solution was added at $0{ }^{\circ} \mathrm{C}$ carboxylic acid $7(101 \mathrm{mg}, 0.43 \mathrm{mmol})$, EDC $(92 \mathrm{mg}, 0.48 \mathrm{mmol})$, HOAt (0.5 M solution in DMF, $1 \mathrm{~mL}, 0.48 \mathrm{mmol})$, and $\mathrm{NaHCO}_{3}(34 \mathrm{mg}, 0.4 \mathrm{mmol})$. The resulting solution was allowed to warm to $22{ }^{\circ} \mathrm{C}$ and stirred for $14 \mathrm{~h}$. The reaction was quenched by the addition of a saturated solution of $\mathrm{NaHCO}_{3}$, and the mixture was washed with EtOAc $(10 \mathrm{~mL} \times 3)$. The organic layers were washed with brine, dried over $\mathrm{Na}_{2} \mathrm{SO}_{4}$, and concentrated in vacuo. The residue was purified by silica gel chromatography (1:1 hexanes:EtOAc to 10:10:1 hexanes:EtOAc:MeOH) to afford the desired methyl ester as a yellow solid ( $164 \mathrm{mg}, 0.29 \mathrm{mmol}, 73 \%$ overall yield for two steps). IR (neat): 3384, 2978, 1739, 1663, 1503, $1361 \mathrm{~cm}^{-1} . \quad{ }^{1} \mathrm{H} \mathrm{NMR}\left(\mathrm{CDCl}_{3}, 400 \mathrm{MHz}\right): \delta 8.33$ (br, 1H), $8.27(\mathrm{~s}, 2 \mathrm{H}), 7.85(\mathrm{~s}, 1 \mathrm{H}), 7.57$ $(\mathrm{d}, J=8.0 \mathrm{~Hz}, 1 \mathrm{H}), 7.53(\mathrm{~s}, 2 \mathrm{H}), 7.10(\mathrm{~s}, 1 \mathrm{H}), 4.95(\mathrm{dt}, J=8.0,5.6 \mathrm{~Hz}, 1 \mathrm{H}), 3.72(\mathrm{~s}, 3 \mathrm{H}), 3.39(\mathrm{~d}, J=5.6 \mathrm{~Hz}, 2 \mathrm{H}), 1.32$ (s, 12H). ${ }^{13} \mathrm{C}$ NMR $\left(\mathrm{CDCl}_{3}, 100 \mathrm{MHz}\right): \delta 182.9,171.2,160.7,153.0,135.9,131.7,129.7,126.5,125.6,124.4,121.4$, 118.4, 117.7, 109.6, 83.6, 53.0, 52.7, 27.7, 24.9. HRMS (ESI): $\mathrm{m} / z$ calcd for $\mathrm{C}_{26} \mathrm{H}_{27} \mathrm{BN}_{2} \mathrm{O}_{7} \mathrm{Cl}_{2} \mathrm{Na}$ : 583.1194, found: $583.1186[\mathrm{M}+\mathrm{Na}]^{+} . \quad[\alpha]_{\mathrm{D}}^{25}=-54.0\left(c=0.88, \mathrm{CHCl}_{3}\right)$. To a solution of derived methyl ester in THF $(6 \mathrm{~mL})$ was added a $0.1 \mathrm{M}$ aqueous solution of $\mathrm{LiOH}(3 \mathrm{~mL})$ in a dropwise manner at $0{ }^{\circ} \mathrm{C}$. The resulting solution was allowed to warm to $22{ }^{\circ} \mathrm{C}$ and stirred for $3 \mathrm{~h}$. The resulting solution was neutralized through addition of a solution of $0.1 \mathrm{M}$ aqueous solution of $\mathrm{NaHSO}_{4}(3 \mathrm{~mL})$ and then washed with EtOAc $(10 \mathrm{~mL} \times 3)$. The organic layers were washed with brine, dried over $\mathrm{Na}_{2} \mathrm{SO}_{4}$, and concentrated in vacuo to give the desired carboxylic acid $\mathbf{8}$, which proved to be of sufficient purity and was therefore used directly with further purification. ${ }^{1} \mathrm{H}$ NMR (acetone- $d_{6}, 400 \mathrm{MHz}$ ): $\delta 10.20$ (br, $1 \mathrm{H}$ ), 8.14 $(\mathrm{d}, J=8.4 \mathrm{~Hz}, 1 \mathrm{H}), 8.10(\mathrm{~s}, 2 \mathrm{H}), 7.85(\mathrm{~s}, 1 \mathrm{H}), 7.65(\mathrm{~d}, J=8.0 \mathrm{~Hz}, 1 \mathrm{H}), 7.40(\mathrm{~d}, J=8.0 \mathrm{~Hz}, 1 \mathrm{H}), 7.37(\mathrm{~d}, J=2.4 \mathrm{~Hz}, 1 \mathrm{H})$, $4.94(\mathrm{dt}, J=8.0,4.8 \mathrm{~Hz}, 1 \mathrm{H}), 3.52(\mathrm{dd}, J=14.8,4.8 \mathrm{~Hz}, 1 \mathrm{H}), 3.39(\mathrm{dd}, J=14.8,8.0 \mathrm{~Hz}, 1 \mathrm{H}), 1.33(\mathrm{~s}, 12 \mathrm{H}) .{ }^{13} \mathrm{C}$ NMR (acetone- $d_{6}, 100 \mathrm{MHz}$ ): $\delta 185.2,171.5,163.0,155.1,137.2,132.0,130.9,127.2,126.2,125.6,122.7,119.4,118.5,110.9$, 84.0, 69.4, 53.9, 28.0, 25.3, 25.2, 19.3. HRMS (ESI): $\mathrm{m} / z$ calcd for $\mathrm{C}_{25} \mathrm{H}_{25} \mathrm{BN}_{2} \mathrm{O}_{7} \mathrm{Cl}_{2} \mathrm{Na}$ : 569.1033, found: 569.1030 $[\mathrm{M}+\mathrm{Na}]^{+}$.

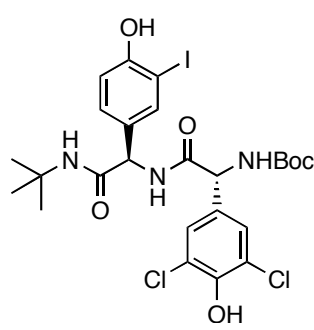

Dipeptide 11. To a solution of $9(640 \mathrm{mg}, 2.0 \mathrm{mmol})$ in DMF $(12 \mathrm{~mL})$ was added NaI (327 $\mathrm{mg}$, $2.2 \mathrm{mmol})$ and chloramine- $\mathrm{T}(614 \mathrm{mg}, 2.2 \mathrm{mmol})$ at $22{ }^{\circ} \mathrm{C}$. The reaction was quenched by the addition of water, and the mixture was washed with EtOAc $(20 \mathrm{~mL} \times 3)$. The organic layers were washed with brine, $1 \mathrm{M}$ aqueous solution of $\mathrm{NaHSO}_{4}, 3 \%$ aqueous solution of $\mathrm{Na}_{2} \mathrm{~S}_{2} \mathrm{O}_{3}$, dried over $\mathrm{Na}_{2} \mathrm{SO}_{4}$, and concentrated in vacuo. The resulting yellow solid was purified by silica gel chromatography (2:1 to $1: 1$ hexanes:EtOAc) to give the desired product as a white solid (833 $\mathrm{mg}, 1.86 \mathrm{mmol}, 94 \%$ yield). ${ }^{1} \mathrm{H} \mathrm{NMR}\left(\mathrm{CDCl}_{3}, 400 \mathrm{MHz}\right): \delta 7.60(\mathrm{~d}, J=2.0 \mathrm{~Hz}, 1 \mathrm{H}), 7.08$ (s, 1H), 7.07 (dd, $J=8.4,2.0 \mathrm{~Hz}, 1 \mathrm{H}), 6.65$ (d, $J=8.4 \mathrm{~Hz}, 1 \mathrm{H}), 5.77$ (br, 1H), 5.68 (br, 1H), 4.89 (br, 1H), 1.43 (s, 9H), 1.32 (s, 9H). ${ }^{13} \mathrm{C} \mathrm{NMR}\left(\mathrm{CDCl}_{3}, 100 \mathrm{MHz}\right): \delta 170.2,157.0,155.5,138.9,134.1,129.3,115.6,84.0,79.4,60.5,57.7,51.7$, 
28.7, 28.5. $[\alpha]^{25}{ }_{\mathrm{D}}=-78.2(c=1.0, \mathrm{MeOH})$. Gaseous $\mathrm{HCl}$ was introduced for five min. to a solution of the abovementioned amino acid $(40 \mathrm{mg}, 0.086 \mathrm{mmol})$ dissolved in anhydrous $\mathrm{MeOH}(1 \mathrm{~mL})$ and cooled to $0{ }^{\circ} \mathrm{C}$. The solution was then allowed to warmed to $22^{\circ} \mathrm{C}$, and after being allowed to stir for $1 \mathrm{~h}$, TLC analysis (1:1 hexanes:EtOAc, $\mathrm{Rf}=0.27)$ indicated complete consumption of the starting material. Solvent was removed in vacuo to afford a white solid. To the solid was added a solution of saturated $\mathrm{NaHCO}_{3}$ while stirring until $\mathrm{pH}=8$. The resulting mixture was washed with EtOAc ( $5 \mathrm{~mL}$ x 3), and the combined organic layers were washed with brine, dried over $\mathrm{Na}_{2} \mathrm{SO}_{4}$, and concentrated in vacuo to afford the desired amine. To this amine was added THF (4 mL), protected amino acid 9 (32 $\mathrm{mg}, 0.095 \mathrm{mmol})$, DEPBT $(31 \mathrm{mg}, 0.10 \mathrm{mmol})$, and $\mathrm{NaHCO}_{3}(7 \mathrm{mg}, 0.086 \mathrm{mmol})$ at $0^{\circ} \mathrm{C}$. The resulting solution was allowed to warm to $22{ }^{\circ} \mathrm{C}$ and stirred for $11 \mathrm{~h}$. The reaction was quenched by the addition of a saturated solution of $\mathrm{NaHCO}_{3}$, and the reaction mixture was extracted with $\operatorname{EtOAc}(5 \mathrm{~mL}$ x 3). The organic layers were washed with brine, dried over $\mathrm{Na}_{2} \mathrm{SO}_{4}$, and concentrated in vacuo. The residue was purified by silica gel chromatography (1:1 to 1:2 hexanes:EtOAc) to afford the desired dipeptide 11 as a white solid (44 $\mathrm{mg}, 0.066 \mathrm{mmol}, 77 \%$ overall yield for two steps). IR (neat): 3326, 2976, 1699, 1681, 1653, 1488, 1367, $1163 \mathrm{~cm}^{-1} . \quad{ }^{1} \mathrm{H}$ NMR (acetone- $d_{6}, 400 \mathrm{MHz}$ ): $\delta 9.11$ (br, $1 \mathrm{H}$ ), 8.82 (br, 1H), $8.13(\mathrm{br}, 1 \mathrm{H}), 7.78(\mathrm{~d}, J=2.0 \mathrm{~Hz}, 1 \mathrm{H}), 7.45(\mathrm{~s}, 2 \mathrm{H}), 7.26(\mathrm{dd}, J=8.4,2.0 \mathrm{~Hz}, 1 \mathrm{H}), 7.08(\mathrm{~s}, 1 \mathrm{H}), 6.84(\mathrm{~d}, J=8.4$ $\mathrm{Hz}, 1 \mathrm{H}), 6.69(\mathrm{~d}, J=6.4 \mathrm{~Hz}, 1 \mathrm{H}), 5.39-5.35(\mathrm{~m}, 2 \mathrm{H}), 1.39(\mathrm{~s}, 9 \mathrm{H}), 1.24(\mathrm{~s}, 12 \mathrm{H}) . \quad{ }^{13} \mathrm{C}$ NMR (acetone- $\left.d_{6}, 100 \mathrm{MHz}\right): \delta$ 169.8, 169.5, 157.0, 155.7, 149.5, 138.9, 132.9, 132.8, 129.5, 128.5, 122.5, 115.6, 84.2, 79.9, 57.6, 56.7, 51.7, 28.7, 28.5. HRMS (ESI): $m / z$ calcd for $\mathrm{C}_{25} \mathrm{H}_{30} \mathrm{~N}_{3} \mathrm{O}_{6} \mathrm{Cl}_{2} \mathrm{INa}$ : 688.0450, found: $688.0454[\mathrm{M}+\mathrm{Na}]^{+} . \quad[\alpha]^{25}=-68.9(c=1.47, \mathrm{MeOH})$.

Tripeptide 12. Gaseous $\mathrm{HCl}$ was introduced for $5 \mathrm{~min}$ to a cooled $\left(0{ }^{\circ} \mathrm{C}\right)$ solution of dipeptide $\mathbf{1 1}(123 \mathrm{mg}, 0.18 \mathrm{mmol})$ in anhydrous $\mathrm{MeOH}(4 \mathrm{~mL})$. The resulting solution was allowed to warm to $22{ }^{\circ} \mathrm{C}$ and allowed to stir for $1 \mathrm{~h}$ after which solvent was removed in vacuo to afford a white solid. To this solid was added a solution of saturated $\mathrm{NaHCO}_{3}$. The resulting mixture was extracted with EtOAc $(5 \mathrm{~mL}$ x 3), and the combined organic layers were washed with brine, dried over $\mathrm{Na}_{2} \mathrm{SO}_{4}$, and concentrated in vacuo to afford the desired amine. To this amine $(25.5 \mathrm{mg}, 42.5 \mu \mathrm{mol})$ was added THF $(2 \mathrm{~mL})$, carboxylic acid $8(25.6 \mathrm{mg}, 46.8 \mu \mathrm{mol})$, HATU $(19.4 \mathrm{mg}, 51.0 \mu \mathrm{mol})$ at $0^{\circ} \mathrm{C}$. The resulting solution was allowed to warm to $22{ }^{\circ} \mathrm{C}$ and stirred for $4 \mathrm{~h}$. The reaction was quenched by the addition of water, and the reaction mixture was extracted with EtOAc $(5 \mathrm{~mL} \times 3)$. The organic layers were washed with brine, dried over $\mathrm{Na}_{2} \mathrm{SO}_{4}$, and concentrated in vacuo. The residue was purified by silica gel chromatography $\left(20: 1 \mathrm{CH}_{2} \mathrm{Cl}_{2}: \mathrm{MeOH}\right)$ to afford the desired tripeptide 12 as a yellow solid (32.1 mg, $29.3 \mu \mathrm{mol}, 69 \%)$. IR (neat): 3288, 2976, 1646, 1506, 1489, 1363, 1216, $1144 \mathrm{~cm}^{-1} . \quad{ }^{1} \mathrm{H}$ NMR (acetone- $\left.d_{6}, 400 \mathrm{MHz}\right): \delta 10.02(\mathrm{br}, 1 \mathrm{H}), 8.32(\mathrm{~d}, J=7.2 \mathrm{~Hz}, 1 \mathrm{H}), 8.25(\mathrm{~d}, J=7.6 \mathrm{~Hz}, 1 \mathrm{H}), 8.23(\mathrm{~d}$, $J=8.4 \mathrm{~Hz}, 1 \mathrm{H}), 8.03(\mathrm{~s}, 2 \mathrm{H}), 7.84(\mathrm{~s}, 1 \mathrm{H}), 7.80(\mathrm{~d}, J=2.0 \mathrm{~Hz}, 1 \mathrm{H}), 7.66(\mathrm{~d}, J=6.0 \mathrm{~Hz}, 1 \mathrm{H}), 7.44(\mathrm{~s}, 2 \mathrm{H}), 7.36(\mathrm{~d}, J=$ $8.0 \mathrm{~Hz}, 1 \mathrm{H}), 7.30(\mathrm{~d}, J=2.4 \mathrm{~Hz}, 1 \mathrm{H}), 7.25(\mathrm{dd}, J=8.4,2.0 \mathrm{~Hz}, 1 \mathrm{H}), 7.05(\mathrm{~s}, 1 \mathrm{H}), 6.87(\mathrm{~d}, J=8.4 \mathrm{~Hz}, 1 \mathrm{H}), 5.78(\mathrm{~d}, J=$ $7.2 \mathrm{~Hz}, 1 \mathrm{H}), 5.37(\mathrm{~d}, J=7.6 \mathrm{~Hz}, 1 \mathrm{H}), 5.08(\mathrm{dt}, J=8.8,4.0 \mathrm{~Hz}, 1 \mathrm{H}), 3.46(\mathrm{dd}, J=14.4,4.8 \mathrm{~Hz}, 1 \mathrm{H}), 3.20(\mathrm{t}, J=14.4 \mathrm{~Hz}$, $1 \mathrm{H}), 1.31(\mathrm{~s}, 12 \mathrm{H}), 1.21(\mathrm{~s}, 9 \mathrm{H}) .{ }^{13} \mathrm{C}$ NMR (acetone- $\left.d_{6}, 100 \mathrm{MHz}\right): \delta 184.8,171.7,170.9,169.5,169.4,163.1,157.1$, 155.6, 149.6, 139.0, 137.1, 132.6, 132.2, 132.0, 131.0, 129.7, 128.6, 126.6, 126.4, 125.6, 122.7, 122.5, 119.4, 118.6, 115.7, 111.0, 84.2, 83.9, 60.5, 57.1, 56.3, 54.7, 51.7, 28.7, 25.2. HRMS (ESI): $\mathrm{m} / z$ calcd. for $\mathrm{C}_{45} \mathrm{H}_{45} \mathrm{BN}_{5} \mathrm{O}_{10} \mathrm{Cl}_{4} \mathrm{INa}_{\mathrm{N}}$ 1116.0968, found: $1116.0956[\mathrm{M}+\mathrm{Na}]^{+} . \quad[\alpha]^{26}{ }_{\mathrm{D}}=-45.6(c=0.96, \mathrm{MeOH})$.

Cyclization of of iodo-boronic ester 12 to macrocycles $(\boldsymbol{R}) \mathbf{- 1 3}$ and $(\boldsymbol{S}) \mathbf{- 1 4}$. A solution of tripeptide $\mathbf{1 2}(10.2 \mathrm{mg}, 9.8$ $\mu \mathrm{mol}), \mathrm{PdCl}_{2}(\mathrm{dppf}) \cdot \mathrm{CH}_{2} \mathrm{Cl}_{2}$ (1 equiv, $\left.7.6 \mathrm{mg}, 9.3 \mu \mathrm{mol}\right)$ and $\mathrm{K}_{2} \mathrm{CO}_{3}(12.9 \mathrm{mg}, 93 \mu \mathrm{mol})$ in degassed 1,4-dioxane: $\mathrm{H}_{2} \mathrm{O}$ (7:1, $4.4 \mathrm{~mL}, 0.002 \mathrm{M}$ solution) was allowed to stir at $80{ }^{\circ} \mathrm{C}$ for $1 \mathrm{~h}$. Volatiles were evaporated in vacuo, the residue was suspended in a mixture of hexanes, ethyl acetate and methanol (5:5:1), chromatographed on a short silica gel column, and concentrated in vacuo. The resulting red solid was purified by silica gel column chromatography (5:5:1 hexanes:ethyl acetate:methanol) to afford an equal mixture of $(R)-\mathbf{1 3}$ and $(S)-\mathbf{1 4}$ in $52 \%$ total yield.

13: ${ }^{1} \mathrm{H}$ NMR (DMSO $\left.-d_{6}, 400 \mathrm{MHz}\right): \delta 10.82(\mathrm{br}, 1 \mathrm{H}), 9.95(\mathrm{~s}, 1 \mathrm{H}), 9.52(\mathrm{~s}, 1 \mathrm{H}), 8.99(\mathrm{br}, 1 \mathrm{H}), 8.45(\mathrm{~d}, J=8.8 \mathrm{~Hz}, 1 \mathrm{H})$, $8.05(\mathrm{~s}, 1 \mathrm{H}), 7.94(\mathrm{~d}, J=8.0 \mathrm{~Hz}, 1 \mathrm{H}), 7.76(\mathrm{~s}, 2 \mathrm{H}), 7.48(\mathrm{~d}, J=8.8 \mathrm{~Hz}, 1 \mathrm{H}), 7.42(\mathrm{~s}, 2 \mathrm{H}), 7.26(\mathrm{~d}, J=10.8 \mathrm{~Hz}, 1 \mathrm{H}), 6.96$ $(\mathrm{d}, J=8.4 \mathrm{~Hz}, 1 \mathrm{H}), 6.86(\mathrm{~d}, J=8.0 \mathrm{~Hz}, 1 \mathrm{H}), 6.80(\mathrm{~d}, J=8.0 \mathrm{~Hz}, 1 \mathrm{H}), 5.82(\mathrm{~s}, 1 \mathrm{H}), 5.80(\mathrm{~d}, J=8.0 \mathrm{~Hz}, 1 \mathrm{H}), 5.10(\mathrm{~d}, J=$ $2.4 \mathrm{~Hz}, 1 \mathrm{H}), 4.15-4.19(\mathrm{~m}, 1 \mathrm{H}), 3.44(\mathrm{t}, J=12.0 \mathrm{~Hz}, 1 \mathrm{H}), 2.85(\mathrm{~d}, J=12.0 \mathrm{~Hz}, 1 \mathrm{H}), 1.29(\mathrm{~s}, 9 \mathrm{H})$. MS (ESI): $m / z$ calcd for $\mathrm{C}_{39} \mathrm{H}_{33} \mathrm{Cl}_{4} \mathrm{~N}_{5} \mathrm{O}_{8} \mathrm{Na}: 862.10$, found: $862.33[\mathrm{M}+\mathrm{Na}]^{+} . \quad[\alpha]^{26}{ }_{\mathrm{D}}=-13.8(c=0.4, \mathrm{DMSO})$. 
14: ${ }^{1} \mathrm{H}$ NMR (acetone- $\left.d_{6}, 400 \mathrm{MHz}\right): \delta 10.02(\mathrm{br}, 1 \mathrm{H}), 8.26(\mathrm{~s}, 2 \mathrm{H}), 7.81(\mathrm{~d}, J=8.4 \mathrm{~Hz}, 1 \mathrm{H}), 7.60(\mathrm{~d}, J=8.4 \mathrm{~Hz}, 1 \mathrm{H})$, $7.39(\mathrm{~d}, J=10.0 \mathrm{~Hz}, 1 \mathrm{H}), 7.33(\mathrm{~s}, 2 \mathrm{H}), 7.07(\mathrm{~d}, J=2.4 \mathrm{~Hz}, 1 \mathrm{H}), 7.05(\mathrm{dd}, J=8.4,2.8 \mathrm{~Hz}, 1 \mathrm{H}), 6.96(\mathrm{~d}, J=8.4 \mathrm{~Hz}, 1 \mathrm{H})$, $6.86(\mathrm{~d}, J=8.4 \mathrm{~Hz}, 1 \mathrm{H}), 5.80(\mathrm{~d}, J=2.8 \mathrm{~Hz}, 1 \mathrm{H}), 5.48-5.43(\mathrm{~m}, 1 \mathrm{H}), 5.26(\mathrm{~d}, J=7.6 \mathrm{~Hz}, 1 \mathrm{H}), 4.95(\mathrm{~d}, J=6.8 \mathrm{~Hz}, 1 \mathrm{H})$, $3.42(\mathrm{dd}, J=13.2,5.2 \mathrm{~Hz}, 1 \mathrm{H}), 3.23(\mathrm{t}, J=13.2 \mathrm{~Hz}, 1 \mathrm{H}), 1.31(\mathrm{~s}, 9 \mathrm{H})$. MS (ESI): $m / z$ calcd for $\mathrm{C}_{39} \mathrm{H}_{33} \mathrm{Cl}_{4} \mathrm{~N}_{5} \mathrm{O}_{8} \mathrm{Na}$ : 862.10, found: $862.10[\mathrm{M}+\mathrm{Na}]^{+} . \quad[\alpha]_{\mathrm{D}}^{25}=+22.9(c=0.07, \mathrm{MeOH})$.
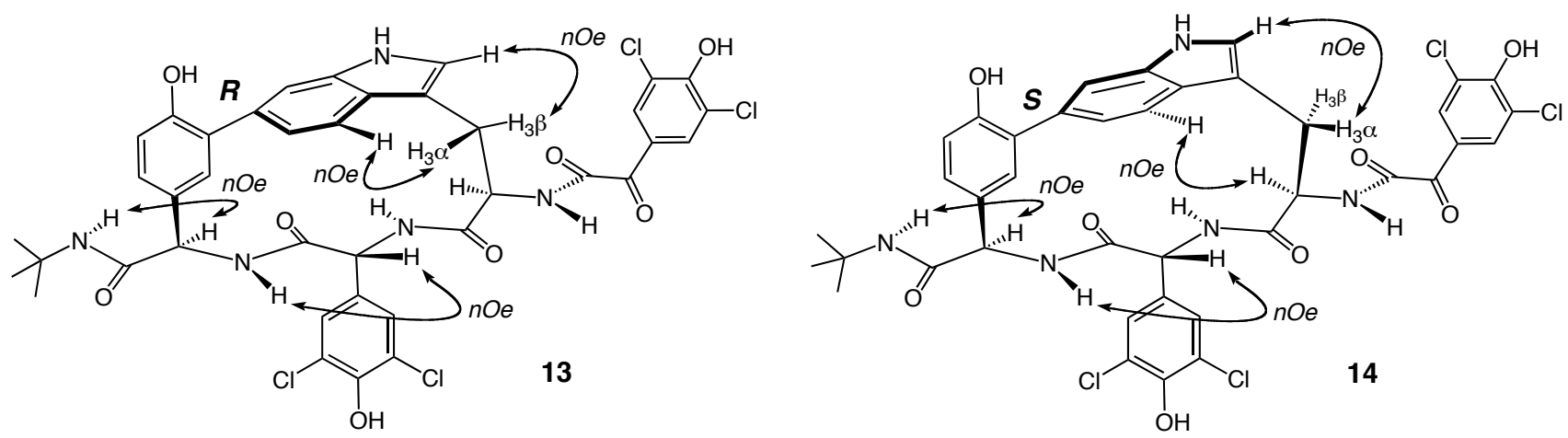

Isomerization of 14 ( $S$ atropisomer) to 15 . A solution of $14(0.8 \mathrm{mg}, 0.95 \mu \mathrm{mol})$ was dissolved in TFA (100 $\mu \mathrm{L})$ and allowed to stir at $50{ }^{\circ} \mathrm{C}$ for $15 \mathrm{~min}$. TFA was removed in vacuo, delivering the desired $\mathbf{1 5}$ as a yellow solid $(0.8 \mathrm{mg}$, $0.95 \mu \mathrm{mol},>98 \%$ yield). ${ }^{1} \mathrm{H}$ NMR (DMSO- $d_{6}, 400 \mathrm{MHz}$ ): $\delta 10.00$ (s, 1H), 9.89 (br, 1H), $9.64(\mathrm{~s}, 1 \mathrm{H}$ ), 8.90 (br, 1H), $8.26(\mathrm{~d}, J=9.6 \mathrm{~Hz}, 1 \mathrm{H}), 8.21(\mathrm{~s}, 1 \mathrm{H}), 7.86(\mathrm{~s}, 2 \mathrm{H}), 7.52(\mathrm{~d}, J=7.6 \mathrm{~Hz}, 1 \mathrm{H}), 7.32(\mathrm{~s}, 2 \mathrm{H}), 7.11(\mathrm{~d}, J=7.4 \mathrm{~Hz}, 1 \mathrm{H}), 7.04(\mathrm{t}$, $J=7.4 \mathrm{~Hz}, 1 \mathrm{H}), 6.98-6.91(\mathrm{~m}, 3 \mathrm{H}), 6.63(\mathrm{~s}, 1 \mathrm{H}), 5.34(\mathrm{t}, J=4.4 \mathrm{~Hz}, 1 \mathrm{H}), 5.25(\mathrm{~s}, 1 \mathrm{H}), 4.40-4.34(\mathrm{~m}, 1 \mathrm{H}), 2.96(\mathrm{t}, J=$ $12.0 \mathrm{~Hz}, 1 \mathrm{H}), 1.30(\mathrm{~s}, 9 \mathrm{H})$. $\quad$ MS (ESI): $\mathrm{m} / z$ calcd for $\mathrm{C}_{39} \mathrm{H}_{33} \mathrm{Cl}_{4} \mathrm{~N}_{5} \mathrm{O}_{8} \mathrm{Na}: 862.10$, found: $862.03[\mathrm{M}+\mathrm{Na}]^{+}$.

Isomerization of $\mathbf{1 3}$ ( $\boldsymbol{R}$ atropisomer) to its corresponding $(R)$ atropisomer. A solution of $\mathbf{1 3}(2.4 \mathrm{mg}, 2.9 \mu \mathrm{mol})$ was dissolved in TFA $(100 \mu \mathrm{L})$ and allowed to stir at $50{ }^{\circ} \mathrm{C}$ for $15 \mathrm{~min}$. TFA was removed in vacuo, delivering the desired $(R)$ atropisomer 15 as a yellow solid $\left(2.4 \mathrm{mg}, 2.9 \mu \mathrm{mol},>98 \%\right.$ yield). ${ }^{1} \mathrm{H}$ NMR (DMSO- $\left.d_{6}, 400 \mathrm{MHz}\right): \delta 10.21(\mathrm{~s}, 1 \mathrm{H})$, 10.67 (br, 1H), $9.53(\mathrm{br}, 1 \mathrm{H}), 9.10(\mathrm{~d}, J=6.4 \mathrm{~Hz}, 1 \mathrm{H}), 8.39(\mathrm{~d}, J=8.8 \mathrm{~Hz}, 1 \mathrm{H}), 8.38(\mathrm{~d}, J=8.8 \mathrm{~Hz}, 1 \mathrm{H}), 8.02(\mathrm{~s}, 1 \mathrm{H})$, $7.87(\mathrm{~s}, 2 \mathrm{H}), 7.61(\mathrm{~s}, 1 \mathrm{H}), 7.42(\mathrm{~s}, 2 \mathrm{H}), 7.24(\mathrm{~d}, J=8.0 \mathrm{~Hz}, 1 \mathrm{H}), 6.98(\mathrm{~d}, J=6.4 \mathrm{~Hz}, 1 \mathrm{H}), 6.97(\mathrm{~d}, J=8.4 \mathrm{~Hz}, 1 \mathrm{H}), 6.96$ $(\mathrm{s}, 1 \mathrm{H}), 6.93(\mathrm{t}, J=8.0 \mathrm{~Hz}, 1 \mathrm{H}), 6.25(\mathrm{~d}, J=2.0 \mathrm{~Hz}, 1 \mathrm{H}), 5.55(\mathrm{~d}, J=8.4 \mathrm{~Hz}, 1 \mathrm{H}), 5.28(\mathrm{~d}, J=8.4 \mathrm{~Hz}, 1 \mathrm{H}), 5.12(\mathrm{dt}, J=$ $12.0,6.8 \mathrm{~Hz}, 1 \mathrm{H}), 3.17(\mathrm{dd}, J=13.4,6.0 \mathrm{~Hz}, 1 \mathrm{H}), 3.05(\mathrm{t}, J=13.4 \mathrm{~Hz}, 1 \mathrm{H}), 1.28(\mathrm{~s}, 9 \mathrm{H})$.

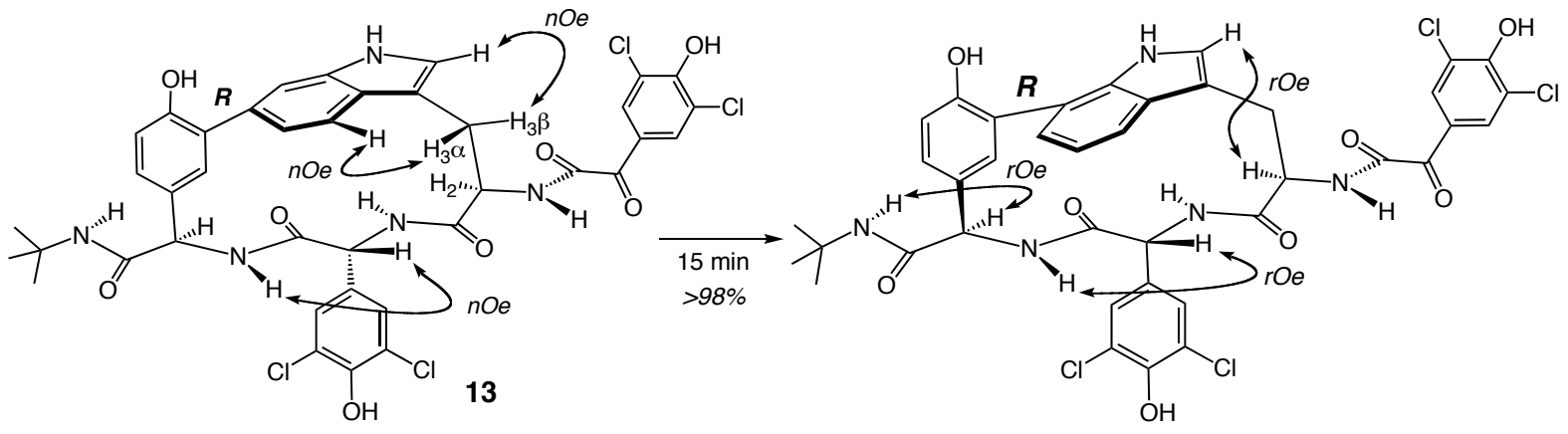

Hexapeptide 17. To amine $\mathbf{1 6}(29.4 \mathrm{mg}, 27.5 \mu \mathrm{mol})$ was added THF $(2 \mathrm{~mL})$, carboxylic acid $\mathbf{8}(16.6 \mathrm{mg}, 30.3 \mu \mathrm{mol})$, and HATU $(12.5 \mathrm{mg}, 33.0 \mu \mathrm{mol})$ at $0{ }^{\circ} \mathrm{C}$. The resulting solution was allowed to stir for $2 \mathrm{~h}$, then warmed to $22{ }^{\circ} \mathrm{C}$, and stirred for $2 \mathrm{~h}$. The reaction was quenched by the addition of water, and the resulting mixture was washed with EtOAc $(5 \mathrm{~mL} \times 3)$. The organic layers were washed with brine, dried over $\mathrm{Na}_{2} \mathrm{SO}_{4}$, and concentrated in vacuo to yield a yellow solid. The solid was purified by silica gel chromatography (5:5:1 hexanes:EtOAc:MeOH) to give the desired hexapeptide 17 as a yellow solid $\left(37.4 \mathrm{mg}, 23.4 \mu \mathrm{mol}, 85 \%\right.$ yield). ${ }^{1} \mathrm{H}-\mathrm{NMR}$ (acetone- $d_{6}, 400 \mathrm{MHz}$ ): $\delta 10.13(\mathrm{br}, 1 \mathrm{H}$ ), 8.21-8.25 (br, 3H), 8.03 (s, 2H), 7.85 (s, 2H), 7.72-7.68 (m, 2H), 7.41 (s, 2H), 7.38-7.35 (m, 2H), 7.29 (s, 2H), 7.19 (dd, $J$ 
$=2.0,8.0 \mathrm{~Hz}, 1 \mathrm{H}), 6.92(\mathrm{~d}, J=9.2 \mathrm{~Hz}, 1 \mathrm{H}), 6.90(\mathrm{dd}, J=8.8 \mathrm{~Hz}, 2 \mathrm{H}), 6.80(\mathrm{dd}, J=8.8 \mathrm{~Hz}, 2 \mathrm{H}), 6.32(\mathrm{br}, 1 \mathrm{H}), 5.93(\mathrm{~s}$, $1 \mathrm{H}), 5.84(\mathrm{br}, 1 \mathrm{H}), 5.78(\mathrm{br}, 1 \mathrm{H}), 5.21(\mathrm{~d}, J=6.4 \mathrm{~Hz}, 1 \mathrm{H}), 5.11-4.96(\mathrm{br}, 3 \mathrm{H}), 3.62(\mathrm{~s}, 3 \mathrm{H}), 3.51$ (dd, $J=15.2,4.8 \mathrm{~Hz}$, $1 \mathrm{H}), 3.34-3.40(\mathrm{~m}, 2 \mathrm{H}), 3.10(\mathrm{t}, J=11.6 \mathrm{~Hz}, 1 \mathrm{H}), 3.04(\mathrm{~s}, 3 \mathrm{H}), 1.33(\mathrm{~s}, 12 \mathrm{H})$. HRMS $(\mathrm{ESI}): \mathrm{m} / \mathrm{z}$ calcd for $\mathrm{C}_{68} \mathrm{H}_{59} \mathrm{BN}_{7} \mathrm{O}_{17} \mathrm{Cl}_{16} \mathrm{INa}: 1616.1135$, found: $1616.1134[\mathrm{M}+\mathrm{Na}]^{+} . \quad[\alpha]_{\mathrm{D}}^{25}=-48.1(c=0.8, \mathrm{MeOH})$.

Cyclization of hexapeptide 17 to $\mathrm{Me}$ ester 18. A solution of hexapeptide 17 (18.9 $\mathrm{mg}, 11.8 \mu \mathrm{mol})$, $\mathrm{PdCl}_{2}(\mathrm{dppf}) \cdot \mathrm{CH}_{2} \mathrm{Cl}_{2}$ (1 equiv, $9.6 \mathrm{mg}, 11.8 \mu \mathrm{mol}$ ) and $\mathrm{K}_{2} \mathrm{CO}_{3}$ (10 equiv, $16.3 \mathrm{mg}, 118 \mu \mathrm{mol}$ ) was dissolved in degassed 1,4-dioxane/ $\mathrm{H}_{2} \mathrm{O}(10 / 1,5.5 \mathrm{~mL}, 0.002 \mathrm{M})$ and allowed to stir at $80{ }^{\circ} \mathrm{C}$ for $1.5 \mathrm{~h}$. Volatiles were removed in vacuo, the resulting brown solid was suspended in 3:3:1 hexanes:EtOAc:MeOH, chromatographed on a short silica gel column, and concentrated. The resulting brown solid was purified by silica gel chromatography (5:10:1 hexanes:EtOAc: $\mathrm{MeOH})$ to afford the desired methyl ester (18) as a yellow solid in $63 \%$ yield $(10.0 \mathrm{mg}, 7.4 \mu \mathrm{mol}) .{ }^{1} \mathrm{H}$ NMR (acetone- $d_{6}, 400$ MHz): $\delta 9.94$ (br, 1H), 8.21 (br, 3H), $7.93(\mathrm{~d}, J=8.4 \mathrm{~Hz}, 1 \mathrm{H}), 7.74(\mathrm{dd}, J=8.4,2.0 \mathrm{~Hz}, 1 \mathrm{H}), 7.44(\mathrm{~d}, J=8.8 \mathrm{~Hz}, 1 \mathrm{H})$, $7.40(\mathrm{~s}, 2 \mathrm{H}), 7.37(\mathrm{~s}, 2 \mathrm{H}), 7.30(\mathrm{dd}, J=8.0,2.4 \mathrm{~Hz}, 1 \mathrm{H}), 7.21(\mathrm{~s}, 2 \mathrm{H}), 7.11(\mathrm{dd}, J=8.0,2.4 \mathrm{~Hz}, 1 \mathrm{H}), 7.06(\mathrm{~s}, 1 \mathrm{H}), 6.97$ $(\mathrm{dd}, J=8.4,2.0 \mathrm{~Hz}, 1 \mathrm{H}), 6.86(\mathrm{~d}, J=8.4 \mathrm{~Hz}, 2 \mathrm{H}), 6.80(\mathrm{~d}, J=8.8 \mathrm{~Hz}, 2 \mathrm{H}), 6.20(\mathrm{~d}, J=6.4 \mathrm{~Hz}, 1 \mathrm{H}), 5.65(\mathrm{~s}, 1 \mathrm{H})$, 5.70-5.58 (br, 1H), $5.56(\mathrm{~d}, J=2.4 \mathrm{~Hz}, 1 \mathrm{H}), 5.18(\mathrm{~d}, J=6.4 \mathrm{~Hz}, 1 \mathrm{H}), 5.13(\mathrm{~d}, J=6.0 \mathrm{~Hz}, 1 \mathrm{H}), 4.96$ (dd, $J=12.4,3.2 \mathrm{~Hz}$, $1 \mathrm{H}), 4.81(\mathrm{~d}, J=7.2 \mathrm{~Hz}, 1 \mathrm{H}), 3.60(\mathrm{~s}, 3 \mathrm{H}), 3.44(\mathrm{dd}, J=13.2,4.4 \mathrm{~Hz}, 1 \mathrm{H}), 3.34(\mathrm{dd}, J=14.4,2.4 \mathrm{~Hz}, 1 \mathrm{H}), 3.22(\mathrm{t}, J=$ $13.2 \mathrm{~Hz}, 1 \mathrm{H}), 3.12(\mathrm{dd}, J=14.4,11.6 \mathrm{~Hz}, 1 \mathrm{H}), 3.05(\mathrm{~s}, 3 \mathrm{H})$. HRMS (ESI): $m / z$ calcd for $\mathrm{C}_{62} \mathrm{H}_{47} \mathrm{Cl}_{6} \mathrm{~N}_{7} \mathrm{O}_{15} \mathrm{Na}: 1362.1159$, found: $1362.1202[\mathrm{M}+\mathrm{Na}]^{+} . \quad[\alpha]_{\mathrm{D}}^{26}=+22.3(c=0.14, \mathrm{MeOH})$.

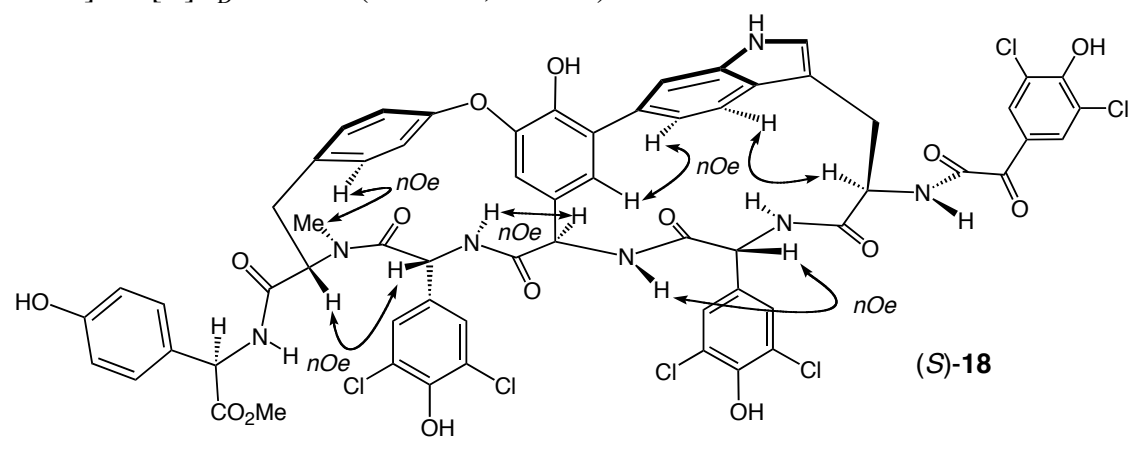

Isocomplestatin (2). To a solution of methyl ester $(S)-\mathbf{1 8}(3.0 \mathrm{mg}, 2.2 \mu \mathrm{mol})$ in THF $(1.5 \mathrm{~mL})$ was added a $0.1 \mathrm{M}$ aqueous solution of $\mathrm{LiOH}(220 \mu \mathrm{L})$ in a dropwise manner at $0{ }^{\circ} \mathrm{C}$. The resulting solution was allowed to stir for $2 \mathrm{~h}$. The mixture was neutralized through addition of a solution of $0.1 \mathrm{M}$ aqueous solution of $\mathrm{HCl}(220 \mu \mathrm{L})$ and concentrated in vacuo. The resulting yellow residue was purified by column chromatography (18:1 EtOAc:MeOH with $0.5 \% \mathrm{HOAc})$ to afford ( $S$ )-isocomplestatin ( 2 ) as a yellow solid ( $2.9 \mathrm{mg}, 2.2 \mu \mathrm{mol},>98 \%$ yield). ${ }^{1} \mathrm{H}-\mathrm{NMR}$ (acetone- $d_{6}, 400 \mathrm{MHz}$ ): $\delta$ $9.95(\mathrm{br}, 1 \mathrm{H}), 8.19(\mathrm{br}, 3 \mathrm{H}), 7.93(\mathrm{~d}, J=8.0 \mathrm{~Hz}, 1 \mathrm{H}), 7.76(\mathrm{~d}, J=8.4 \mathrm{~Hz}, 1 \mathrm{H}), 7.40(\mathrm{~s}, 2 \mathrm{H}), 7.38(\mathrm{~s}, 2 \mathrm{H}), 7.29(\mathrm{~d}, J=8.0$ $\mathrm{Hz}, 1 \mathrm{H}), 7.21(\mathrm{~s}, 2 \mathrm{H}), 7.11(\mathrm{dd}, J=8.4,2.4 \mathrm{~Hz}, 1 \mathrm{H}), 7.06(\mathrm{~s}, 1 \mathrm{H}), 6.98(\mathrm{dd}, J=8.4,2.4 \mathrm{~Hz}, 1 \mathrm{H}), 6.88(\mathrm{~d}, J=8.4 \mathrm{~Hz}, 2 \mathrm{H})$, $6.80(\mathrm{~d}, J=8.4 \mathrm{~Hz}, 2 \mathrm{H}), 6.18(\mathrm{~d}, J=5.2 \mathrm{~Hz}, 1 \mathrm{H}), 5.64(\mathrm{~s}, 1 \mathrm{H}), 5.64-5.58(\mathrm{br}, 1 \mathrm{H}), 5.56(\mathrm{~s}, 1 \mathrm{H}), 5.18(\mathrm{~d}, J=6.4 \mathrm{~Hz}, 1 \mathrm{H})$, $5.11(\mathrm{~d}, J=5.6 \mathrm{~Hz}, 1 \mathrm{H}), 4.96(\mathrm{~d}, J=10.8 \mathrm{~Hz}, 1 \mathrm{H}), 4.80(\mathrm{~d}, J=7.2 \mathrm{~Hz}, 1 \mathrm{H}), 3.44(\mathrm{dd}, J=13.2,5.2 \mathrm{~Hz}, 1 \mathrm{H}), 3.36(\mathrm{~d}, J=$ $13.4 \mathrm{~Hz}, 1 \mathrm{H}), 3.22(\mathrm{t}, J=13.2 \mathrm{~Hz}, 1 \mathrm{H}), 3.10(\mathrm{t}, J=13.2 \mathrm{~Hz}, 1 \mathrm{H}), 3.02(\mathrm{~s}, 3 \mathrm{H})$. HRMS (ESI): $\mathrm{m} / z$ calcd for $\mathrm{C}_{61} \mathrm{H}_{45} \mathrm{Cl}_{6} \mathrm{~N}_{7} \mathrm{O}_{15} \mathrm{Na}: 1348.0958$, found: $1348.1003[\mathrm{M}+\mathrm{Na}]^{+} . \quad[\alpha]^{26}{ }_{\mathrm{D}}=+36.0(c=0.15,2: 1 \mathrm{MeOH} / 0.01 \mathrm{~N}$ aqueous $\mathrm{NaOH}$ ). 


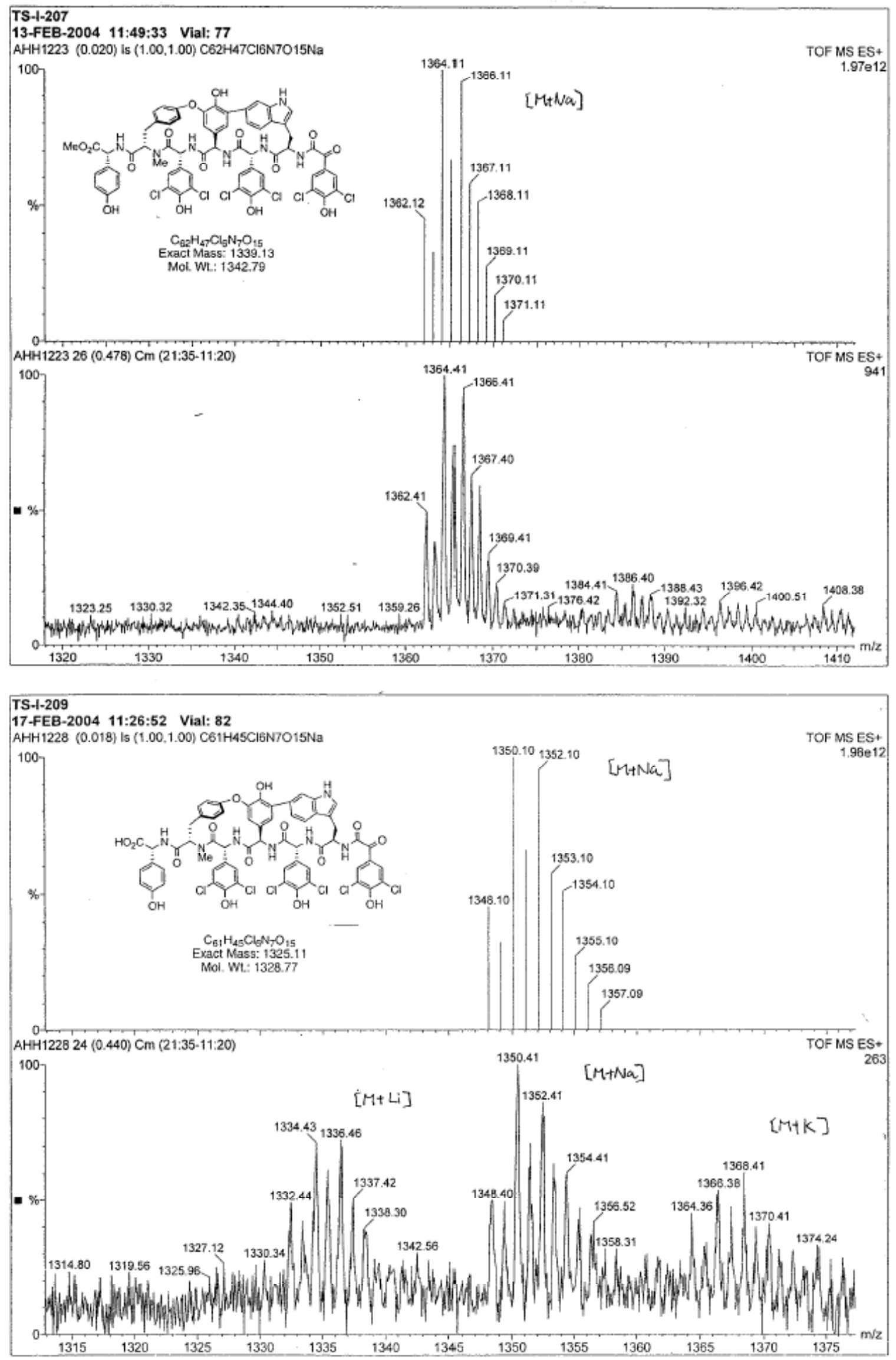




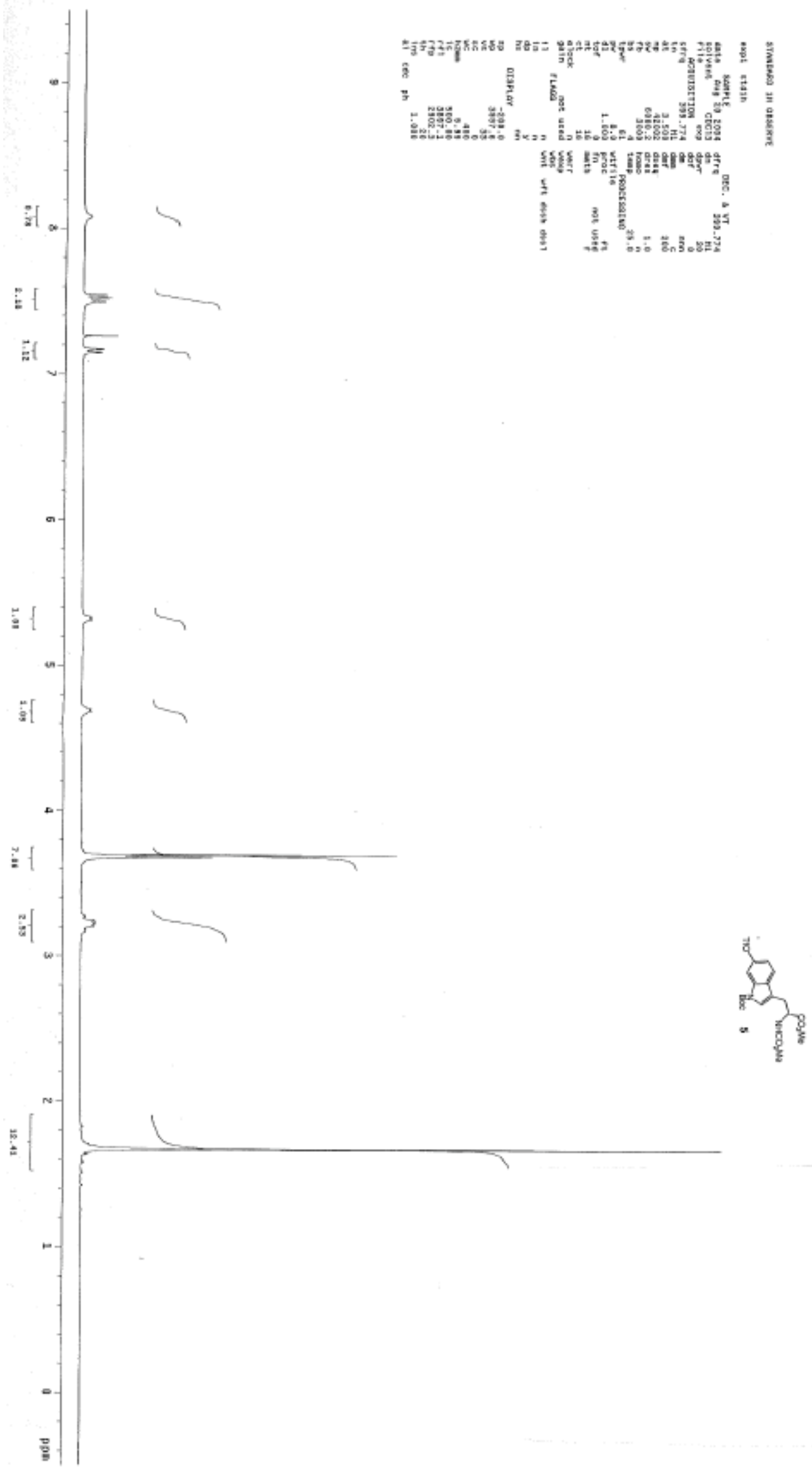



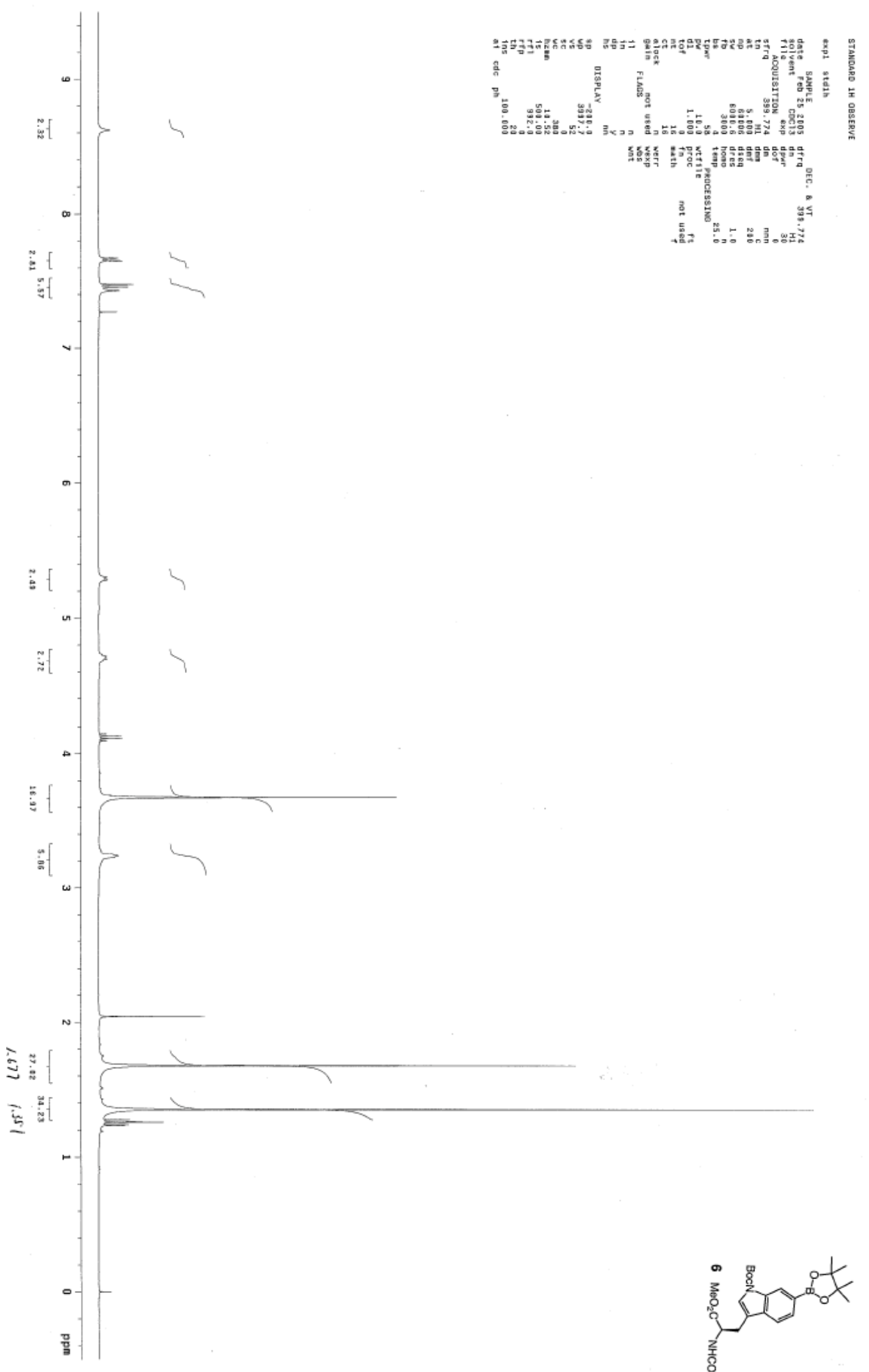


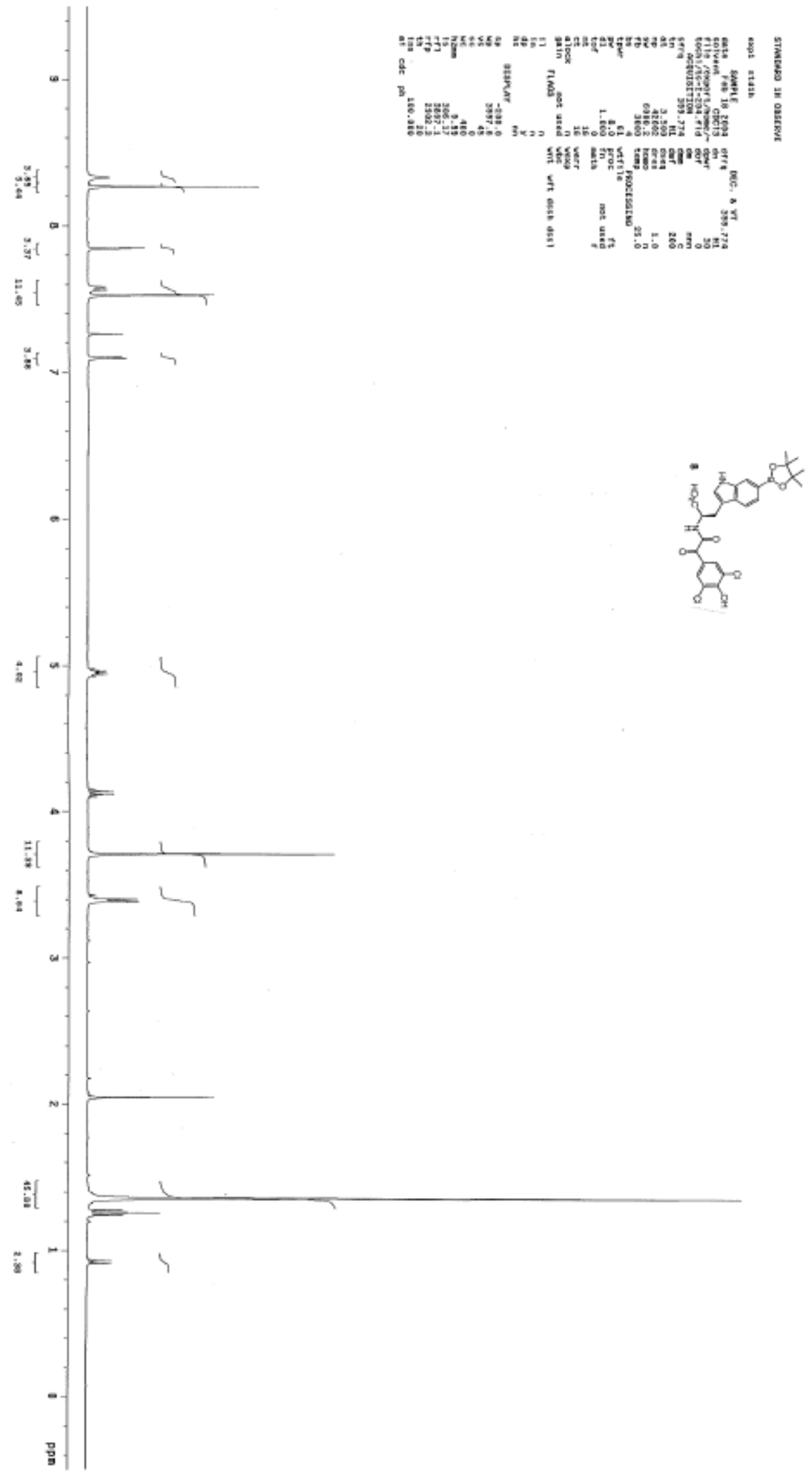




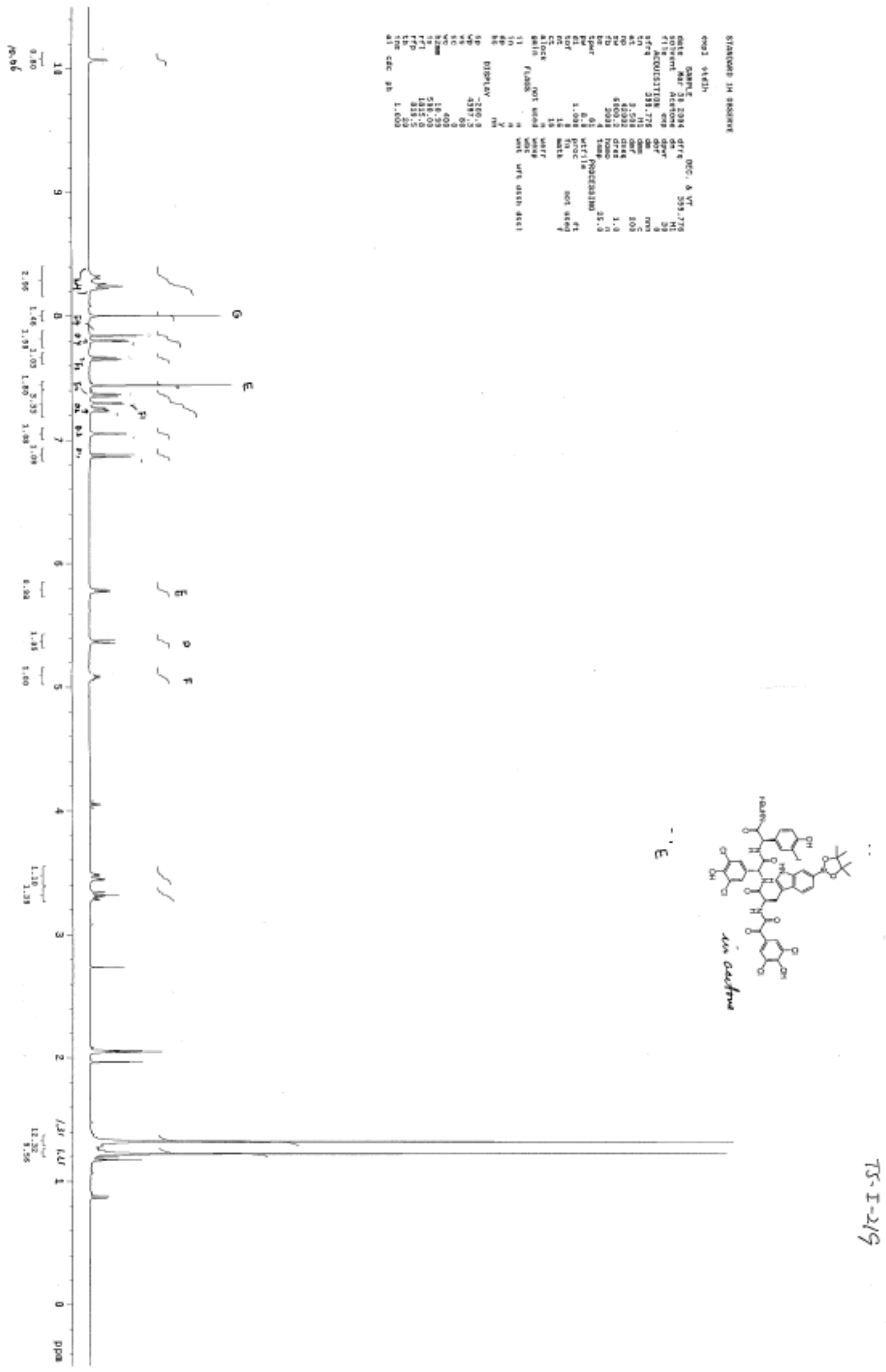




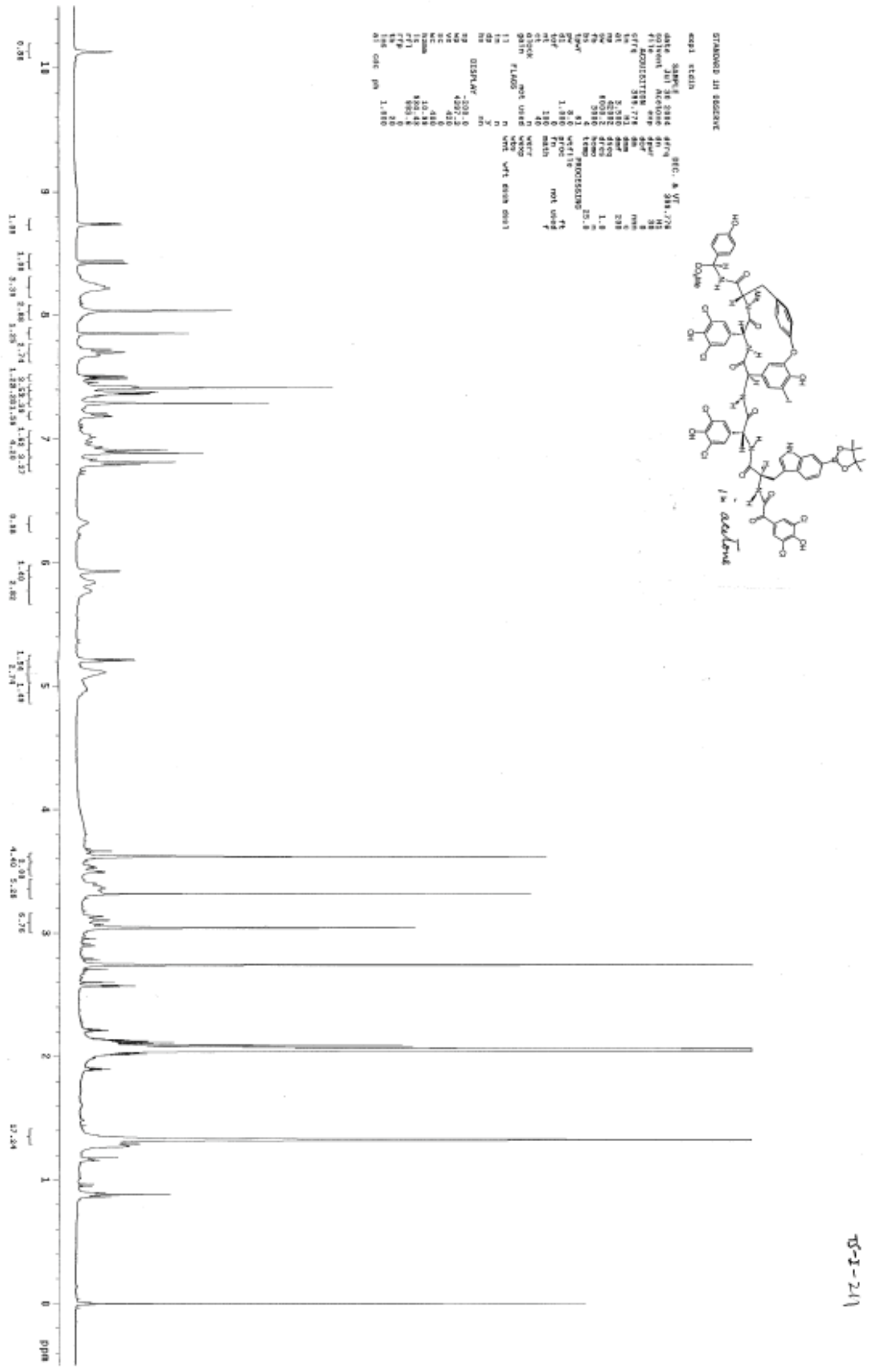




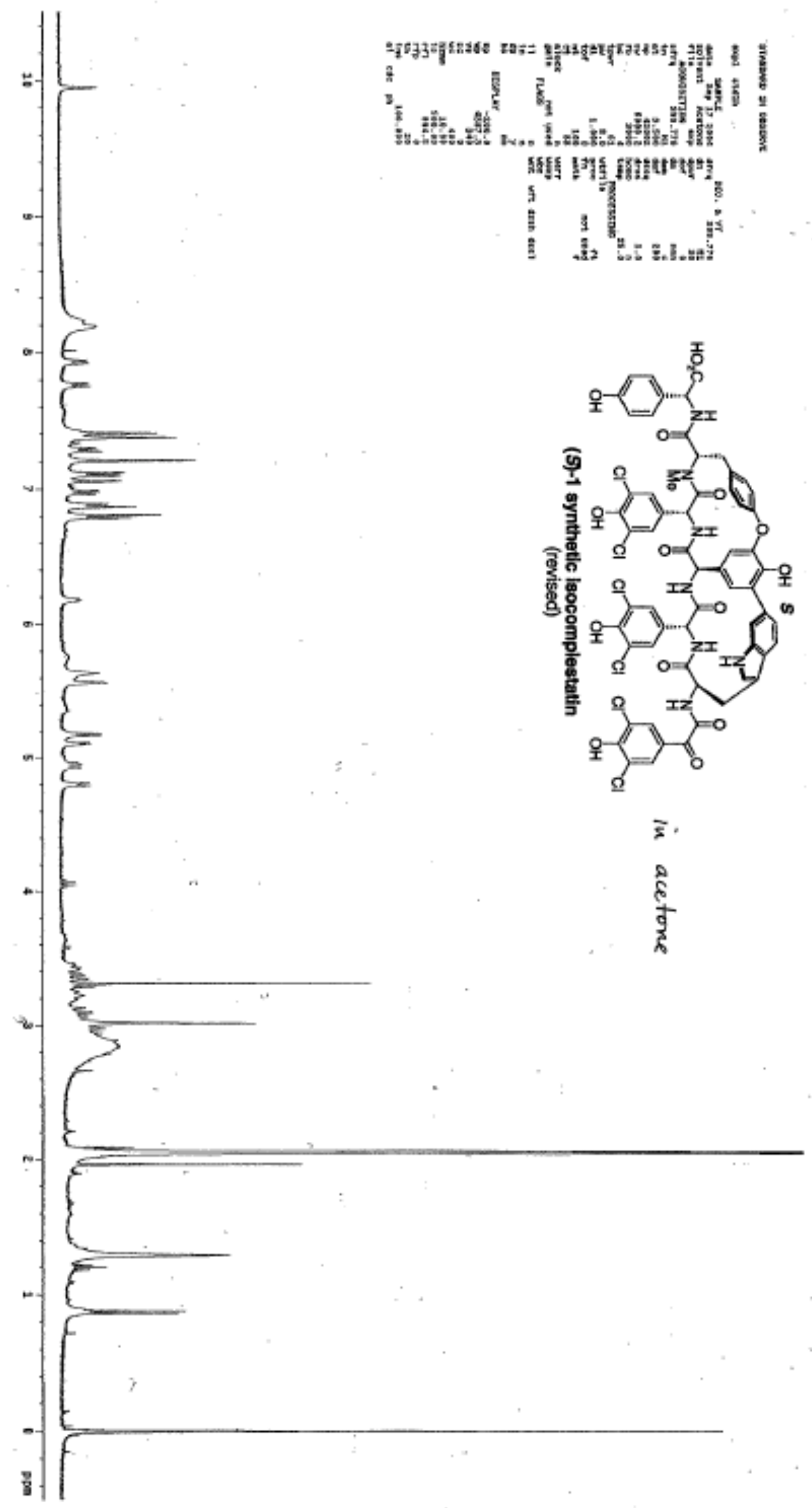


Shinohara, et al., Page S13

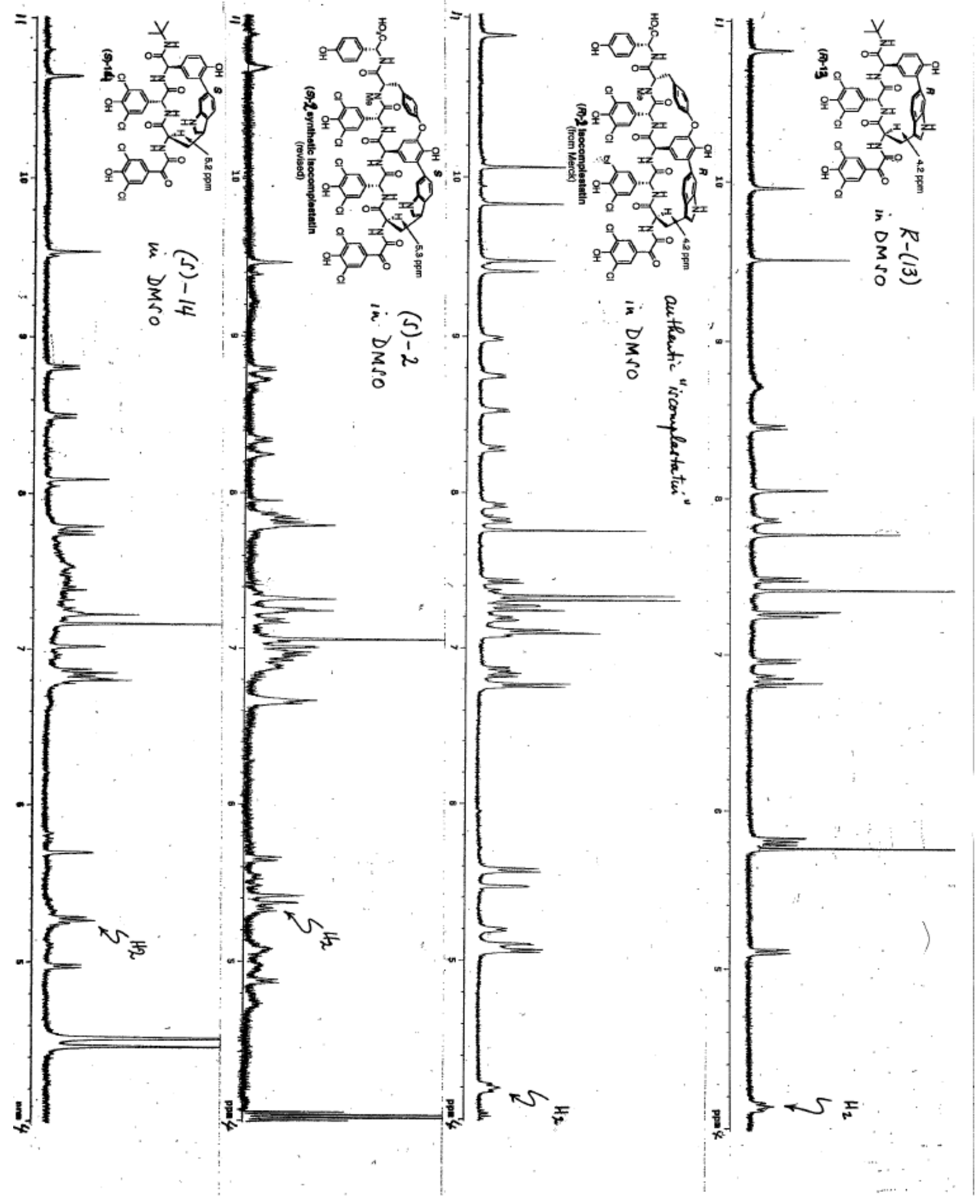

